\title{
Peningkatan Hasil Belajar Siswa pada Tema 7 Perkembangan Teknologi Melalui Model Pembelajaran Problem Based Learning di Kelas III SDN Karangreja 01 Kabupaten Brebes
}

\author{
Jumi Astiti*, Ervina Eka Subekti, Kuswandari \\ Program Studi Pendidikan Profesi Guru, Pendidikan Guru Sekolah Dasar \\ Universitas PGRI Semarang \\ *Corresponding Author. Email: jumiastiti2@gmail.com
}

\begin{abstract}
The purpose of this study was to improve student learning outcomes on theme 7 of technological development through a problem based learning model in class III SDN Karangreja 01 Brebes Regency. This research method used classroom action research which consists of three cycles. The subjects of this study were students in class III, amounting to 22 people. The data collection technique in this study was through test and non-test methods, while the data analysis technique used descriptive analysis. The results of this study indicate that the learning outcomes of students in the first cycle get an average score of 62.0 , in the second cycle the average score is 67.50 and in the third cycle the average score is 82.50 . So the conclusion of this study is that through the Problem Based Learning model, it can improve student learning outcomes.
\end{abstract}

\begin{abstract}
Abstrak: Tujuan penelitian ini adalah untuk meningkatkan hasil belajar peserta didik pada tema 7 perkembangan teknologi melalui model problem based learning di kelas III SDN Karangreja 01 Kabupaten Brebes. Metode penelitian ini menggunakan penelitian tindakan kelas yang terdiri dari tiga siklus. Subyek penelitian ini adalah peserta didik pada kelas III yang berjumlah 22 orang. Teknik pengumpulan data dalam penelitian ini adalah melalui metode tes dan non tes, sedangkan teknik analisis datanya menggunakan analisis deskriptif. Hasil penelitian ini menunjukkan bahwa hasil belajar peserta didik pada siklus I perolehan rata-rata nilai 62,0 , pada siklus II rata-rata perolehan nilai 67,50 dan pada siklus III perolehan rata-rata nilai 82,50. Sehingga kesimpulan dari penelitian ini adalah melalui model pembelajaran Problem Based Learning dapat meningkatkan hasil belajar peserta didik
\end{abstract}

\section{Article History}

Received: 24-05-2021

Revised: $15-06-2021$

Accepted: 24-06-2021

Published: 07-07-2021

Key Words:

Problem Based

Learning, Learning

Outcomes,

Thematic.

\section{Sejarah Artikel}

Diterima: 24-05-2021

Direvisi: 15-06-2021

Disetujui: 24-06-2021

Diterbitkan: 07-07-2021

\section{Kata Kunci:}

Problem Based Learning, Hasil Belajar, Tematik

How to Cite: Astiti, J., Subekti, E., \& Kuswandari, K. (2021). Peningkatan Hasil Belajar Siswa pada Tema 7 Perkembangan Teknologi Melalui Model Pembelajaran Problem Based Learning di Kelas III SDN Karangreja 01 Kabupaten Brebes. Jurnal Paedagogy, 8(3), 357-363. doi:https://doi.org/10.33394/jp.v8i3.3901

dc. https://doi.org/10.33394/jp.v8i3.3901

This is an open-access article under the CC-BY-SA License.

\section{Pendahuluan}

Pembelajaran pada Kurikulum 2013 merupakan suatu sistem pembelajaran yang memungkinkan peserta didik, baik secara individual maupun kelompok, aktif menggali dan menemukan konsep serta prinsip-prinsip keilmuan secara holistik, bermakna dan autentik. Pembelajaran terpadu berorientasi pada praktik pembelajaran yang sesuai dengan kebutuhan dan perkembangan peserta didik. Pembelajaran tematik memberikan kesempatan kepada anak didik untuk mengembangkan tiga ranah pendidikan yaitu kognitif, afektif dan psikomotor secara bersamaan. Oleh karena itu, melalui pembelajaran tematik diharapkan peserta didik memiliki kompetensi sikap, pengetahuan dan keterampilan sehingga anak didik lebih bisa produktif, kreatif dan inovatif (Rusman, 2014).

Proses pembelajaran di dalam kelas terdapat banyak faktor yang dapat mempengaruhi kualitas pembelajaran selain kemampuan guru, suasana peserta didik, suasana lingkungan, 
perencanaan pembelajaran, bahan pembelajaran dan media pembelajaran juga perlu adanya strategi pembelajaran atau cara yang dilakukan oleh guru dalam menyampaikan bahan pembelajaran kepada peserta didik dengan memperhatikan suasana peserta didik. Proses pembelajaran agar lebih efektif, inovatif dan kreatif pembelajaran tidak sekedar menerima dengan pasif akan tetapi pembelajaran harus bisa dipahami oleh peserta didik dan peserta didik bersikap lebih aktif terlibat langsung dalam proses pembelajaran yang dibimbing oleh guru menuju lingkungan kelas yang nyaman dan kondisi emosional, sosiologis, psikologis, dan fisiologis yang kondusif (Huda, 2014; Suarni et al., 2021; Roshida, 2020). Dalam proses pembelajaran tujuan akhirnya adalah mendapatkan hasil belajar yang baik. Menurut Asep Jihad dan Abdul Haris (2013), hasil belajar merupakan pencapaian bentuk perubahan perilaku yang cenderung menetap dari ranah kognitif, afektif, dan psikomotoris dari proses belajar yang dilakukan dalam waktu tertentu. Setelah siswa melakukan proses belajar maka siswa diharapkan dapat mencapai tujuan pembelajaran yang telah ditetapkan. Siswa dapat dikatakan berhasil dalam belajar adalah siswa yang dapat mencapai tujuan pembelajaran yang telah ditetapkan tersebut. Model pembelajaran Problem Based Learning adalah pemberian masalah yang berhubungan dengan kehidupan sehari-hari kepada siswa kemudian siswa secara berkelompok mencari alternatif solusi untuk menyelesaikan masalah tersebut. Sedangkan menurut Dutch (dalam Amir 2009; Akbar, 2019). Problem Based Learning merupakan metode instruksional yang menantang siswa agar belajar untuk belajar, bekerja sama dalam kelompok untuk mencari solusi bagi masalah yang nyata masalah ini diguakan untuk mengingatkan rasa keingintahuan serta kemampuan analitis dan inisiatif atas materi pelajaran.

Berdasarkan hasil observasi pada kelas III yang dilaksanakan di SDN Karangreja 01 Brebes menunjukkan bahwa pencapaian hasil pembelajaran siswa masih kurang optimal. Faktor dasar yang mempengaruhi pencapaian hasil belajar siswa kurang optimal adalah kurangnya keaktifan siswa dalam proses pembelajaran, dimana dalam proses pembelajaran peserta didik merasa malu bertanya dan malu ketika diminta mengungkapkan pendapatnya dan masih banyak peserta didik yang berbicara sendiri sehingga tidak mendengarkan penjelasan guru ketika pembelajaran berlangsung yang menyebabkan hasil belajar peserta didik rendah. Asumsi dasar yang menyebabkan pencapaian hasil belajar peserta didik kurang optimal adalah kurangnya peran aktif peserta didik dalam proses pembelajaran, dimana dalam proses pembelajaran guru belum menggunakan model pembelajaran yang tepat untuk meningkatkan keaktifan belajar peserta didik, guru belum mampu menarik perhatian peserta didik untuk aktif mengikuti proses pembelajaran sehingga peserta didik kurang bersemangat untuk mengikuti pembelajaran, hal ini membuat peserta didik menjadi kurang paham akan materi yang diajarkan oleh guru didepan kelas. kemudian dalam pemberian tugas guru hanya memberikan tugas berupa pengerjaan soal-soal yang ada dibuku paket. Peserta didik tidak diberikan tugas untuk menyelesaikan masalah yang ada dilingkungan sekitar dari hasil pemikirannya sendiri yang berkaitan dengan materi yang sedang dipelajari, sehingga proses pembelajaran yang selama ini dilaksanakan kurang memberikan ruang kepada peserta didik untuk mengolah pemikirannya secara aktif dan mandiri hal ini membuat peserta didik tidak aktif dalam proses pembelajaran. Dengan begitu, maka potensi yang dimiliki anak tidak akan terasah dan berkembang. Peserta didik harus dilatih untuk berfikir kritis, menganalisis, menyelesaikan permaalahan yang diberikan guru dan mengambil kesimpulan sendiri mengenai pengetahuan yang baru ia dapatkan.

Berdasarkan permasalahan di atas, salah satu alternatif yang dapat digunakan untuk meningkatkan hasil belajar peserta didik dalam kegiatan pembelajaran tematik adalah model 
pembelajaran Problem Based Learning. Problem Based Learning adalah pemberian masalah yang berhubungan dengan kehidupan sehari-hari kepada peserta didik kemudian peserta didik secara berkelompok mencari alternatif solusi untuk menyelesaikan masalah tersebut. Sedangkan menurut Dutch (dalam Amir 2009). Problem Based Learning merupakan metode instruksional yang menantang peserta didik agar belajar untuk belajar, bekerja sama dalam kelompok untuk mencari solusi bagi masalah yang nyata masalah ini diguakan untuk mengingatkan rasa keingintahuan serta kemampuan analitis dan inisiatif atas materi pelajaran. Sebelum pembelajar mempelajari suatu hal, mereka diharuskan mengidentifikasi suatu masalah, baik yang dihadapi secara nyata maupun telah kasus. Masalah diajukan sedemikian rupa sehingga para pembelajar menemukan kebutuhan belajar yang diperlukan agar mereka dapat memecahkan masalah tersebut dengan motivasi yang tinggi.

Adapun tujuan penelitian ini adalah untuk meningkatkan hasil belajar peserta didik pada tema 7 perkembangan teknologi melalui model problem based learning di kelas III SDN Karangreja 01 Kabupaten Brebes.

\section{Metode Penelitian}

Metode penelitian yang digunakan pada peneltian ini adalah penelitian tindakan kelas (PTK). Menurut Suparno (2009) penelitian tindakan kelas adalah penelitian tindakan yang dilakukan oleh guru dengan tujuan untuk memperbaiki mutu pelaksanaan pembelajaran di kelasnya. Dengan demikian PTK berfokus pada proses belajar mengajar yang terjadi di kelas dan dilakukan pada situasi yang sebenarnya (alami). Hal ini berarti bahwa tindakan tersebut merupakan suatu kegiatan yang sengaja dirancang untuk dilakukan oleh siswa dengan tujuan tertentu. Penelitian tindakan kelas ini dilaksanakan dalam tiga siklus. Arikunto (2010) menjelaskan bahwa satu siklus PTK terdiri dari empat tahapan yaitu: (1) perencanaan, (2) pelaksanaan, (3) pengamatan dan (4) refleksi.

Tempat pelaksanaan penelitian tindakan kelas ini adalah di SDN Karangreja 01 yang terletak di desa Karangreja Kecamatan Tanjung Kabupaten Brebes Provinsi Jawa Tengah. Untuk waktu pelaksanaannya adalah di bulan April sampai bulan Mei. Subyek penelitian ini adalah belajar peserta didik pada kelas III SDN Karangreja 01 yang berjumlah 22 peserta didik yang terdiri dari 12 perempuan dan 10 laki-laki. Penelitian dilakukan bersama kolaborator yakni rekan sejawat guru SDN Krangreja 01. Penelitian dilaksanakan sebanyak tiga kali, dengan satu siklus terdiri dari dua pertemuan. Sumber data yang digunakan dalam penelitian ini adalah : 1) Data Peserta didik. Berisi tentang identitas peserta didik beserta hasil belajar peserta didik mulai dari siklus I sampai siklus III. 2) Data dokumen. Berisi tentang nilai awal peserta didik, serta dokumentasi selama penelitian dilakukan. 3) Data guru. Berisi data mengenai keterampilan guru dan instrumen pengamatan. Teknik pengumpulan data dalam penelitian ini adalah melalui metode tes dan non tes. Sedangkan teknik analisis datanya menggunakan analisis deskriptif.

\section{Hasil Penelitian dan Pembahasan}

Penelitian ini dilaksanakan sebanyak tiga siklus, karena pada siklus ketiga data yang diperoleh telah mencapai indikator keberhasilan yang ditentukan. Berdasarkan evaluasi pembelajaran Tema 7 perkembangan teknologi melalui model pembelajaran Problem Based Learning (PBL) pada peserta didik kelas III SDN Karangreja 01 pada siklus I dibandingkan dengan data awal yang ada diperoleh data sebagai berikut: 
Tabel 1. Perbandingan Hasil Belajar Prasiklus dan Siklus I

\begin{tabular}{llcc}
\hline No & Pencapaian & Data Awal & Data Siklus I \\
\hline 1 & Nilai terendah & 40 & 45 \\
\hline 2 & Nilai tertinggi & 75 & 80 \\
\hline 3 & Rata-rata & 57,50 & 62,05 \\
\hline 4 & Jumlah peserta didik belum tuntas & 13 & 8 \\
\hline 5 & Jumlah peserta didik tuntas & 9 & 14 \\
\hline 6 & Presentase Ketuntasan & $40,91 \%$ & $63,64 \%$ \\
\hline 7 & Kategori & Rendah & Sedang \\
\hline
\end{tabular}

Dari hasil data di atas, dapat diketahui bahwa jumlah peserta didik yang tuntas meningkat dibandingkan pada tahap siklus I pembelajaran I. Dari jumlah 22 peserta didik, 14 peserta didik berhasil mencapai KKM dan 11 peserta didik belum mencapai KKM sehingga prosentase ketuntasan yang diperoleh sebesar 63,64\%. Nilai rata-rata yang diperoleh peserta didik kelas III pada tema 7 Perkembangan teknologi subtema 3 Pembelajaran 2 adalah 62,05 Nilai rata-rata tersebut seharusnya mencapai 75, selain itu Indikator keberhasilan hasil belajar ranah kognitif belum mencapai 75\% dari jumlah peserta didik memenuhi KKM sehingga bisa disimpulkan bahwasanya hasil belajar peserta didik belum mencapai ketuntasan. Berdasarkan evaluasi pembelajaran Tema 7 perkembangan teknologi melalui model pembelajaran Problem Based Learning (PBL) pada peserta didik kelas III SDN Karangreja 01 pada siklus II dibandingkan dengan data awal yang ada diperoleh data sebagai berikut:

Tabel 2. Perbandingan Prasiklus, Siklus I dan Siklus II

\begin{tabular}{llccc}
\hline No & Pencapaian & Pra siklus & \multicolumn{1}{l}{ SI } & SII \\
\hline 1 & Nilai terendah & 40 & 45 & 55 \\
\hline 2 & Nilai tertinggi & 75 & 80 & 85 \\
\hline 3 & Rata-rata & 57,50 & 62,05 & 67,50 \\
\hline 4 & Jumlah peserta didik belum tuntas & 13 & 8 & 6 \\
\hline 5 & Jumlah peserta didik tuntas & 9 & 14 & 16 \\
\hline 6 & Presentase Ketuntasan & $40,91 \%$ & $63,64 \%$ & $72,73 \%$ \\
\hline 7 & Kategori & Rendah & Sedang & Sedang \\
\hline
\end{tabular}

Dari hasil data di atas, dapat diketahui bahwa jumlah peserta didik yang tuntas meningkat dibandingkan pada tahap siklus I. Dari jumlah 22 peserta didik, 16 peserta didik berhasil mencapai KKM dan 6 peserta didik belum mencapai KKM sehingga prosentase ketuntasan yang diperoleh sebesar $72,73 \%$. Nilai rata-rata yang diperoleh peserta didik kelas III pada tema 7 perkembangan teknologi subtema 4 Subtema 7 adalah 67,50. Nilai rata-rata tersebut seharusnya mencapai 75 , selain itu indikator keberhasilan hasil belajar ranah kognitif belum mencapai $75 \%$ dari jumlah peserta didik memenuhi KKM sehingga bisa disimpulkan bahwasanya hasil belajar peserta didik belum mencapai ketuntasan. Untuk mengatasi permasalahan tersebut, akan direncanakan siklus III yaitu dengan merevisi RPP, penggunaan media yang lebih menarik dan interaktif, dan penggunaan media aplikasi online yang lebih menarik, kegiatan pembelajaran diselipkan permainan kecil agar perserta didik tidak jenuh, Dengan pengguanaan media yang interaktif diharapkan peserta didik dapat lebih aktif dalam mengikuti pembelajaran.

Berikut evaluasi pembelajaran Tema 7 perkembangan teknologi melalui model pembelajaran Problem Based Learning (PBL) pada peserta didik kelas III SDN Karangreja 01 pada siklus III dibandingkan dengan data awal yang ada diperoleh data sebagai berikut: 
Tabel 3. Perbandingan Prasiklus, Siklus I, Siklus II dan Siklus III

\begin{tabular}{llcccc}
\hline No & Pencapaian & Pra siklus & SI & SII & SIII \\
\hline 1 & Nilai terendah & 40 & 45 & 55 & 60 \\
\hline 2 & Nilai tertinggi & 75 & 80 & 85 & 95 \\
\hline 3 & Rata-rata & 57,50 & 62,05 & 67,50 & 82,50 \\
\hline 4 & Jumlah peserta didik belum tuntas & 13 & 8 & 6 & 3 \\
\hline 5 & Jumlah peserta didik tuntas & 9 & 14 & 16 & 19 \\
\hline 6 & Presentase Ketuntasan & $40,91 \%$ & $63,64 \%$ & $72,73 \%$ & $86,36 \%$ \\
\hline 7 & Kategori & Sedang & Sedang & Sedang & Tinggi \\
\hline
\end{tabular}

Dari hasil data di atas, dapat diketahui bahwa jumlah peserta didik yang tuntas meningkat dibandingkan pada tahap siklus III. Dari jumlah 22 peserta didik, 19 peserta didik sudah berhasil mencapai KKM dan 3 peserta didik belum mencapai KKM sehingga diperoleh presentase ketuntasan yang diperoleh sebesar $86,36 \%$. Nilai rata-rata yang diperoleh peserta didik kelas III pada tema 7 Perkembangan Teknologi subtema 4 adalah 82,50. Nilai rata-rata tersebut sudah mencapai 75 . Berdasarkan hasil pengamatan tersebut terlihat ada peningkatan partisipasi atau keterlibatan siswa dalam proses pembelajaran, karena perolehan nilai yang dicapai pada siklus III sudah mencapai $86,36 \%$ ( sudah $>75 \%$ ), maka kegiatan perbaikan pembelajaran berhenti di siklus III ini.

Hasil penelitian sejalan dengan penelitian yang dilakukan oleh Yuavian (2020) dengan judul "Meningkatkan Hasil Belajar Peserta didik Menggunakan Model pembelajaran Problem Based Learning" Penelitian tersebut dilakukan pada Peserta didik kelas V SD Negeri Depok. Pada pembelajaran pra siklus hasil penelitian tindakan kelas peserta didik yang tuntas sebanyak 6peserta didik dari 22 anak atau $27 \%$ dari $100 \%$, dengan nilai rata-rata 63. Pada siklus I sebanyak 12peserta didik dari 22 anak atau 54\% dari 100\%, dengan nilai rata-rata 67. Selanjutnya pada siklus II sebanyak 19 peserta didik dari 22 anak atau $81 \%$ dari $100 \%$, dengan nilai rata-rata 78 . Kesimpulan penelitian ini adalah hasil belajar IPA peserta didik kelas V SD Negeri 5 Depok Tahun Pelajaran 2019/2020. pada pembelajaran dapat meningkat melalui penerapanmodel pembelajaran Problem Based Learning (PBL) dapat meningkatkan hasil belajar peserta didik.

Penelitian tindakan kelas ini dilakukan untuk mengetahui peningkatan hasil belajar peserta didik kelas III SDN Karangreja 01 dengan menggunakan model pembelajaran Problem Based learning (PBL). Peningkatan hasil belajar peserta didik ini dapat dilihat dari pra siklus sampai ke Siklus III. Hal tersebut dapat dilihat dari uraian sebagai berikut.

\section{Presentase Ketuntasan Hasil Belajar Peserta Didik (\%)}

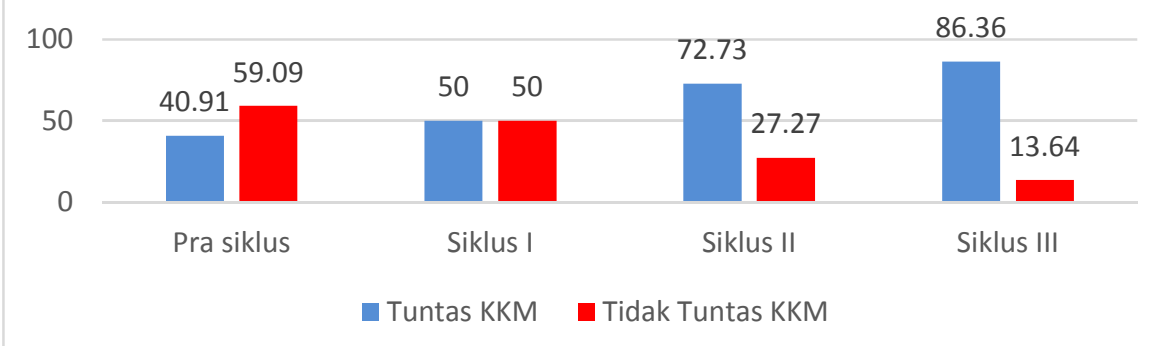

Diagram 1. Peningkatan Hasil Belajar Peserta Didik 
Berdasarkan data tersebut menunjukan bahwa pelaksanaan perbaikan pembelajaran yang dilakukan selama 3 siklus ini menunjukan adanya peningkatan hasil belajar dan ketuntasan belajar yang sangat memuaskan. Berdasarkan diagram tersebut terbukti adanya peningkatan hasil belajar peserta didik. Peningkatan hasil belajar peserta didik telah memenuhi kriteria yang ditentukan oleh peneliti yaitu Ketuntasan kelas dikatakan tuntas apabila banyaknya peserta didik yang mencapai KKM mencapai $75 \%$ dari keseluruhan jumlah peserta didik dan capaian rata-rata yang diperoleh sebesar 275,00 . Sehingga dapat disimpulkan bahwa penelitian ini telah berhasil karena dua variabel penelitian menunjukkan peningkatan dan target yang telah ditetapkan pada tiap siklusnya telah tercapai. Meningkatnya hasil belajar siswa dari perbaikan pembelajaran ini menunjukan bahwa pelaksanaan perbaikan pembelajaran yang dilakukan meningkatkan hasil belajar peserta didik pada tema 7 perkembangan teknologi melalui model pembelajaran problem based learning di kelas III SDN Karangreja 01 Brebes.

\section{Kesimpulan}

Kesimpulan dari penelitian ini adalah melalui model pembelajaran Problem Based Learning dapat meningkatkan hasil belajar peserta didik. Hal ini ditunjukkan dengan perolehan data hasil belajar peserta didik pada siklus I dengan nilai terendah 45, nilai tertinggi 80 rata- rata 62,50 dan ketuntasan klasikal 63,64\%. Pada pelaksaanaan tindakan siklus II diperoleh data dengan nilai terendah 55, nilai tertinggi 85 dengan rata-rata 67,50 dan ketuntasan klasikal $72,73 \%$. Pada pelaksanaan tindakan siklus III hasil belajar peserta didik yang diperoleh dengan nilai terendah 60, nilai tertinggi 95, rata- rata 82,50 dan persentase ketuntasan klasikal $86,36 \%$. Hasil belajar peserta didik sudah memenuhi indikator keberhasilan yaitu sekurangkurangnya ketuntasan klasikal mencapai 75\% dengan KKM di kelas III SDN Karangreja 01 tahun ajaran 2020/2021 adalah 66. Hal ini dapat disimpulkan bahwa hasil belajar peserta didik mengalami peningkatan mulai dari siklus I sampai siklus III. Peningkatan hasil belajar peserta didik sudah memenuhi kriteria yang ditentukan oleh peneliti yaitu ketuntasan belajar sekurang-kurangnya $75 \%$ dari seluruh jumlah peserta didik kelas III dan diperoleh capaian rata-rata sebesar $\geq 75,00$.

\section{Saran}

Saran dalam penelitian ini antara lain adalah: (1) Guru dapat melakukan usaha-usaha peningkatan kualitas pembelajaran melalui pengembangan model pembelajaran Problem Based Learning (PBL) untuk meningkatkan hasil belajar peserta didik. (2) Peserta didik hendaknya lebih aktif dalam pembelajaran sehingga dapat meningkatkan hasil belajar. Peserta didik hendaknya belajar lebih giat agar mendapatkan nilai yang baik. (3) Sekolah hendaknya memfasilitasi guru dengan pengadaan sarana dan prasarana pembelajaran yang memadai agar dapat meningkatkan kualitas pembelajaran di sekolah tersebut.

\section{Daftar Pustaka}

Abdul, Majid. (2014). Strategi Pembelajaran. Bandung. (p.80,90,91): PT Remaja Rosdakarya.

Akbar, A. (2019). Implementasi Model Pembelajaran Berbasis Masalah untuk Meningkatkan Hasil Belajar Siswa pada Mata Pelajaran PKn di SMA Negeri 1 Batukliang Utara. Jurnal Kependidikan: Jurnal Hasil Penelitian dan Kajian Kepustakaan di Bidang Pendidikan, Pengajaran dan Pembelajaran, 5(1), 1-7. doi:https://doi.org/10.33394/jk.v5i1.1386 
Amir, M. (2009). Inovasi Pendidikan melalui Problem Based Learning (p.21). Jakarta: Perdana Media Group.

Dimyati \& Mudjiono. (2006). Belajar dan Mengajar (p.3-4). Jakarta: Rineka Cipta.

Hamdayana, Jumanta. (2014). Model dan Metode Pmbelajaran Kreatif (p.209). Jakarta: Ghalia Indonesia.

Hamalik, Oemar. (2005). Kurikulum dan Pembelajaran. (p.27). Jakarta: Bumi Aksara.

Huda, M. (2014). Model-Model Pengajaran dan Pembelajaran. (p.7). Yogyakarta:Pustaka Pelajar.

Reza Yafian. (2020) “ Meningkatkan Hasil Belajar Peserta didik Menggunakan Model pembelajaran Problem Based Learning (Pbl)".Jurnal Riset Pendidikan Dasar.

Rifa'I, Achmad dan Catharina Tri Anni. (2011). Psikologi Pendidikan. (p.84) Semarang: UNNES Press.

Rosidha, A. (2020). Peningkatan Aktivitas dan Hasil Belajar Siswa pada Mata Pelajaran Biologi Melalui Model Pembelajaran Make and Match Berbasis Media Karu Pintar. Jurnal Paedagogy, 7(4), 393-401. doi:https://doi.org/10.33394/jp.v7i4.2946

Rusman. (2014). Model-model Pembelajaran.(p.254-255). Bandung: PT. Raja Grafindo Persada.

Sagala, Syaiful (2010). Supervisi Pembelajaran dalam Pendidikan. (p.30). Bandung: Alfabeta.

Sudjana, Nana. (2009). Penilaian Hasil Belajar. (p.3) Bandung: PT. Remaja Rosdakarya

Sugiharto, dkk. Psikologi Pendidikan. (p.76-77). Yogyakarta: UNY Press

Suarni, G., Rizka, M., \& Zinnurain, Z. (2021). Analisis Pengaruh Penerapan Model Pembelajaran Sains Teknologi Masyarakat Terhadap Hasil Belajar Siswa. Jurnal Paedagogy, 8(1), 31-38. doi:https://doi.org/10.33394/jp.v8i1.3226

Trianto. (2010). Model Pembelajaran Terpadu, Konsep, Strategi Implementasinya dalam KTSP. (p.1). Jakarta: Bumi Aksara

UU Republik Indonesia nomor 20 tahun 2003. Sistem Pendidikan Nasional. 2003. Bandung: Sinar Grafika. 